\title{
MODIFIKASI STRUKTUR GEDUNG DENGAN BETON PRACETAK PADA APARTEMEN THE CONEXIO
}

\author{
Adita Devania ${ }^{1}$, Andrias Rudi Hermawan ${ }^{2 *}$ \\ 1,2Jurusan Teknik Sipil, Politeknik Negeri Jakarta, Jl. Prof. Dr. G.A. Siwabessy, Kampus Baru UI, Beji, \\ Kukusan, Beji, Kota Depok, Tlp. 021 7270036, Fax (021) 7270034 \\ e-mail:dita.devania@gmail.com \\ ${ }^{*}$ Korespondensi: andrias.rudihermawan@sipil.pnj.ac.id
}

\begin{abstract}
The Conexio Appartements in actual condition are designed using conventional reinforced concrete method and does not have good quality. While in the project also often afected by the weather. The use of precast concrete are having some excellence of them are not affected by the weather, well maintained quality, and earthquake resistant. The connection between the precast elements play an important role in precast buildings to make the buildings resistant to earthquake. This modification is intended to created earthquake resistant precast building according to SNI 2847:2013 with good quality control. In this study, the building will be modified into 8 floors precast building as planned and reviewed which will be analyzed by ETABS. From the results of the modification according to SNI 1726:2012 and SNI 2847:2013 we obtained, main beam dimension 40x60cm, secondary beam $35 x 55 \mathrm{~cm}$, column dimension $65 x 65 \mathrm{~cm}$, overtopping $6 \mathrm{~cm}$ for slab and using Splice sleeve grout for column to column connection, lap splices $500 \mathrm{~mm}$ for beam-column connection, and $30 x 40 \mathrm{~cm}$ for concrete consol dimension.
\end{abstract}

Keywords : Precast, Splice Sleeve, Wet Connection.

\begin{abstract}
ABSTRAK
Apartemen The Conexio pada kondisi sebenarnya dirancang menggunakan metode konvensional dengan kondisi mutu yang kurang baik. Dalam pelaksanannya, proyek tersebut juga sering terganggu oleh cuaca. Penggunaan beton pracetak memiliki beberapa keunggulan diantaranya pelaksanaannya tidak terpengaruh oleh cuaca, memiliki mutu yang terjaga dan tahan gempa. Sambungan antar elemen pracetak sangat berperan penting dalam bangunan dengan beton pracetak yang tahan gempa sehingga perlu diperhitungkan sesuai dengan peraturan. Modifikasi ini ditujukan untuk menghasilkan gedung dengan pracetak yang tahan gempa sesuai dengan SNI 2847:2013 dengan pengendalian mutu yang baik. Dalam studi ini, gedung tersebut akan dilakukan modifikasi struktur menjadi beton pracetak dengan tinjauan 8 lantai dan analisa dibantu dengan software ETABS. Dari hasil modifikasi yang dilakukan, elemen-elemen pracetak sesuai dengan ketentuan SNI 1726:2012 dan SNI 2847:2013 yaitu meliputi ukuran balok induk 40x60cm, ukuran balok anak $35 x 55 \mathrm{~cm}$, dengan kolom berdimensi $65 x 65$ cm, tebal overtopping $6 \mathrm{~cm}$ pada pelat dan menggunakan Splice sleeve grout pada sambungan kolom, penyambungan balok-kolom dengan panjang penyaluran $500 \mathrm{~mm}$ dan penggunaan konsol pada kolom dengan dimensi $30 x 40 \mathrm{~cm}$.
\end{abstract}

Kata kunci : Beton Pracetak, Splice Sleeve, Sambungan Basah. 


\section{PENDAHULUAN}

Seiring

bertambahnya permintaan tempat tinggal dan lahan yang terbatas, maka terciptalah konsep hunian vertikal yaitu berupa Apartemen. Atas hal tersebut, maka dibutuhkan pembangunan yang cepat dan efisien. Untuk mendukung hal tersebut, maka digunakan beton pracetak. Beton pracetak merupakan pekerjaan beton yang sudah dipersiapkan untuk dicetak dan diberi perawatan pada lokasi yang bukan lokasi akhir (final) sehingga hanya perlu dilakukan pemasangan elemen-elemen beton pracetak pada lapangan konstruksi. Penggunaan beton pracetak, dinilai lebih efisien terutama pada aspek mutu, dikarenakan pengerjaannya yang dilakukan di pabrik dan kualitasnya terkendali dari proses awal hingga akhir (Khakim,2011).

Dalam perencanaan beton pracetak, perlu diperhatikan beberapa hal diantaranya perencanaan tulangan pada saat sebelum komposit, perencanaan tulangan pada saat pengangkatan, dan perencanaan tulangan pada saat elemen pracetak dalam keadaan monolit. Setiap elemenelemen beton pracetak tersebut, pada saat di lapangan perlu dilakukan penyambungan. Penyambungan antar elemen ini, sangat berpengaruh terhadap kekuatan struktur terutama pada daerah rawan gempa. Sehingga harus sambungan antar elemen perlu diperhatikan dengan baik.

Dalam penelitian ini akan dibahas mengenai perencanaan elemen beton pracetak dan penyambungan pada elemen beton pracetak. Jenis penyambungan yang dipilih pada penelitian ini menggunakan sambungan basah karena tergolong monolit sehingga dapat menyerupai konstruksi beton monolit,(Susanto, et.al, 2018). Perencanaan sambungan dan perencanaan penulangan pada elemen beton pracetak, disesuaikan dengan SNI 2847 - 2013 dengan menggunakan
Sistem Rangka Pemikul Momen Khusus (SRPMK) mengikuti yang disyaratkan pada SNI 1726 - 2012 untuk bangunan tahan gempa. Pada perhitungan pengangkatan elemen pracetak, disesuaikan dengan PCI (Precast Concrete Institute) Design Handbook $6^{\text {th }}$ Edition. Pada penyambungan elemen yang menggunakan panjang penyaluran, disesuaikan dengan SNI 2847 - 2013 pasal 12.2.3, dinyatakan pada persamaan berikut:

$$
l_{d}=\left(\frac{f y}{1,1 \lambda \sqrt{f^{\prime} c}} \frac{\psi_{t} \psi_{s} \psi_{s}}{\left(\frac{C_{b}+K_{t r}}{d_{b}}\right)}\right) d_{b}
$$

Keterangan :

$\begin{array}{lll}\lambda & = & \text { Faktor beton agregat } \\ \psi_{\mathrm{e}} & = & \text { Faktor pelapis } \\ \psi_{\mathrm{t}} & = & \text { Faktor lokasi penulangan } \\ \psi_{\mathrm{s}} & = & \text { Faktor ukuran tulangan } \\ \mathrm{cb} & =\text { yang terkecil dari jarak pusat }\end{array}$ tulangan ke permukaan beton terdekat, dan setengah spasi pusat ke pusat batang tulangan.

$\mathrm{Ktr}=$ imdeks tulangan transversal, dimana:

$K_{t r}=\frac{40 A_{t r}}{s n}$

Keterangan :

$\mathrm{N}=$ jumlah batang tulangan yang disambung

$\mathrm{K}_{\mathrm{tr}}=$ diizinkan mneggunakan 0 sebagai penyederhanaan.

\section{METODE PENELITIAN}

Lokasi yang dijadikan tempat penelitian terdapat di Jalan Caman Raya, Jatibening, Pondok Gede, Bekasi, Jawa Barat,tepatnya pada Proyek Apartemen The Conexio. Pengumpulan data berupa data struktur dan denag diberikan oleh PT. Adhi Persada Properti selaku pemilik dari proyek tersebut. Data gempa pada wilayah tersebut didapatkan dari puskim.go.id. Permodelan struktur dan analisa struktur dibantu dengan menggunakan software ETABS 2016, 
dan dilakukan penggambaran dengan software AutoCad.
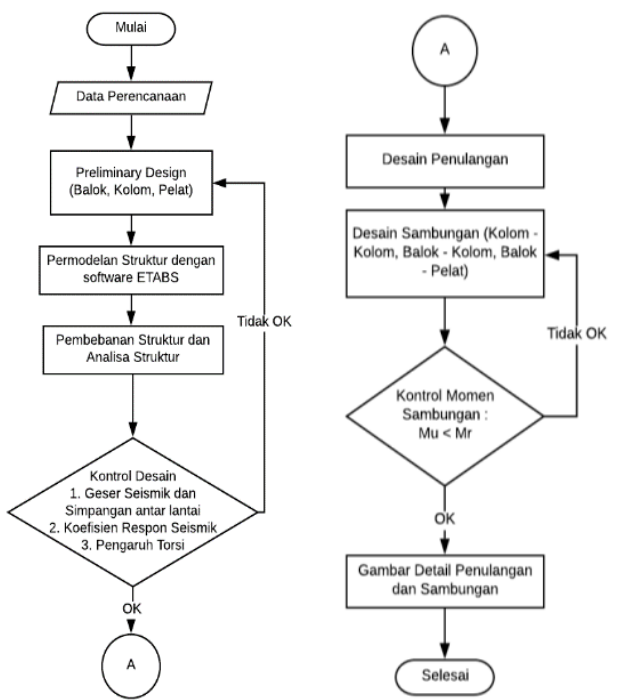

Gambar 1. Bagan Alir Penelitian

\section{HASIL DAN PEMBAHASAN}

\section{Preliminary Design}

Untuk desain awal bangunan disesuaikan dengan denah pada Gambar 2. Hanya ditinjau setinggi 8 lantai.

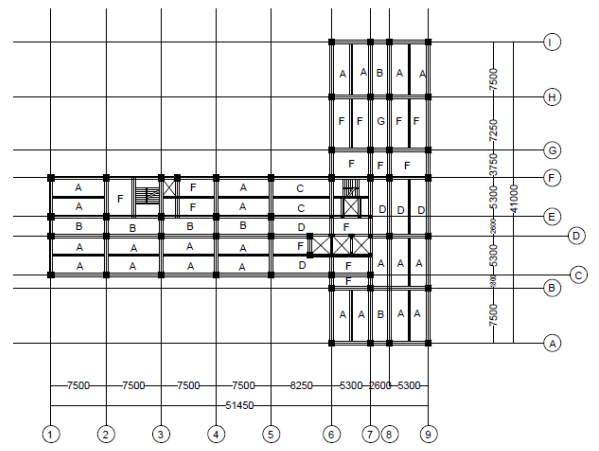

Gambar 2. Denah Balok, Kolom, dan Pelat Tipikal

- Perencanaan Dimensi Balok Perencanaan dimensi balok disesuaikan dengan SNI 2847 - 2013 pasal 9.5.2.1 yang direkapitulasi pada Tabel 1 dan Tabel 2.

Tabel 1. Rekapitulasi Balok Induk

\begin{tabular}{lllllll}
\hline \multirow{2}{*}{ Kode } & Lb & H min & B min & $\begin{array}{l}\text { H } \\
\text { pakai }\end{array}$ & $\begin{array}{l}\text { B } \\
\text { pakai }\end{array}$ & Dimensi \\
\cline { 2 - 7 } & $\mathrm{mm}$ & $\mathrm{mm}$ & $\mathrm{mm}$ & $\mathrm{mm}$ & $\mathrm{Mm}$ & $\mathrm{mm}$ \\
\hline BI1 & 7500 & 448.66 & 299.10 & 600 & 400 & $600 / 400$ \\
\hline BI2 & 8250 & 493.52 & 329.01 & 600 & 400 & $600 / 400$ \\
\hline BI3 & 5600 & 317.05 & 211.36 & 550 & 350 & $550 / 350$ \\
\hline BI4 & 2600 & 155.53 & 103.69 & 450 & 300 & $450 / 300$ \\
\hline BI5 & 7250 & 433.70 & 289.13 & 450 & 300 & $450 / 300$ \\
\hline BI6 & 3750 & 224.33 & 149.55 & 450 & 300 & $450 / 300$ \\
\hline
\end{tabular}

Tabel 2. Rekapitulasi Balok Anak

\begin{tabular}{lllllll}
\hline \multirow{2}{*}{ Kode } & Lb & H min & B min & $\begin{array}{l}\mathbf{H} \\
\text { pakai }\end{array}$ & $\begin{array}{l}\text { B } \\
\text { pakai }\end{array}$ & Dimensi \\
\cline { 2 - 7 } & $\mathrm{mm}$ & $\mathrm{mm}$ & $\mathrm{mm}$ & $\mathrm{mm}$ & $\mathrm{mm}$ & $\mathrm{mm}$ \\
\hline BA1 & 7500 & 341.83 & 227.89 & 500 & 300 & $500 / 300$ \\
\hline BA2 & 8250 & 376.02 & 250.68 & 500 & 300 & $500 / 300$ \\
\hline BA3 & 7250 & 330.44 & 220.29 & 500 & 300 & $500 / 300$ \\
\hline
\end{tabular}

- Perencanaan Dimensi Pelat

Perhitungan dimensi pelat disesuaikan dengan SNI 2847 - 2013 pasal 9.5.2.2, yang direkapitulasi pada Tabel 3.

Tabel 3. Rekapitulasi Dimensi Pelat

\begin{tabular}{cccccc}
\hline Tipe & \multicolumn{2}{c}{ Dimensi } & \multicolumn{2}{c}{ Dimensi Parsial } & Tebal \\
\hline $\begin{array}{c}\text { Tipe } \\
\text { A }\end{array}$ & $750 \times 265$ & $\mathrm{~cm}^{2}$ & $227,5 \times 110$ & $\mathrm{~cm}^{2}$ & $13 \mathrm{~cm}$ \\
\hline Tipe B & $750 \times 260$ & $\mathrm{~cm}^{2}$ & $215 \times 110$ & $\mathrm{~cm}^{2}$ & $13 \mathrm{~cm}$ \\
\hline $\begin{array}{c}\text { Tipe } \\
\text { C }\end{array}$ & $825 \times 265$ & $\mathrm{~cm}^{2}$ & $227,5 \times 150$ & $\mathrm{~cm}^{2}$ & $13 \mathrm{~cm}$ \\
\hline $\begin{array}{c}\text { Tipe } \\
\text { D }\end{array}$ & $825 \times 260$ & $\mathrm{~cm}^{2}$ & $215 \times 150$ & $\mathrm{~cm}^{2}$ & $13 \mathrm{~cm}$ \\
\hline Tipe E & $725 \times 265$ & $\mathrm{~cm}^{2}$ & $227,5 \times 120$ & $\mathrm{~cm}^{2}$ & $13 \mathrm{~cm}$ \\
\hline Tipe F & $530 \times 265$ & $\mathrm{~cm}^{2}$ & $237,5 \times 110$ & $\mathrm{~cm}^{2}$ & $13 \mathrm{~cm}$ \\
\hline $\begin{array}{c}\text { Tipe } \\
\text { G }\end{array}$ & $725 \times 260$ & $\mathrm{~cm} 2$ & $215 \times 110$ & $\mathrm{~cm}^{2}$ & $13 \mathrm{~cm}$ \\
\hline
\end{tabular}

- Perencanaan Dimensi Kolom

Menurut SNI 2847:2013 pasal 9.3.2.2 untuk komponen struktur beron bertulang faktor reduksi, $\phi=0,65$. Mutu beton $35 \mathrm{Mpa}$.

$A=\frac{w}{\phi f c}=\frac{713326,9}{0,65 \times 3,5}=313550,3 \mathrm{~mm}^{2}$

Kolom berbetuk persegi maka:

$\mathrm{H}=\mathrm{B}=\sqrt{ } A=559,5 \mathrm{~mm}$, dipakai $=650$ $\mathrm{mm}$.

Maka dimensi kolom 650/650 mm.

\section{Perencanaan Penulangan dan Pengangkatan Elemen}

- Penulangan Pelat Lantai

Penulangan pelat lantai direncanakan dalam 3 tahapan, sebelum komposit, pada saat pengangkatan, setelah komposit. Kombinasi pembebanan yang digunakan:

$\mathrm{Qu}=1,2 \mathrm{DL}+1,6 \mathrm{LL}$

Dimana:

DL = Beban mati yang bekerja

LL = Beban hidup yang bekerja 


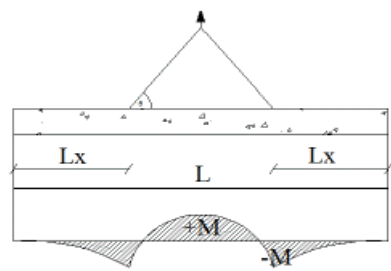

Gambar 3. Titik Pengangkatan

Pada saat pengangkatan, ditentukan empat titik pengangkatan disesuaikan dengan PCI Design Handbook:

$\mathrm{Mx} \quad=0,0107 \mathrm{x} \mathrm{W} \mathrm{x} \mathrm{a}^{2} \mathrm{x} \mathrm{b}$

My $\quad=0,0107 \times \mathrm{W} \times \mathrm{a} \mathrm{x} \mathrm{b}^{2}$

Dimana:

$\mathrm{W} \quad=$ Beban yang terjadi pada setiap titik

$$
\text { a } \quad=\text { Sisi pendek }(\mathrm{Lx})
$$$$
\mathrm{b} \quad=\text { Sisi panjang (Ly) }
$$

Sehingga diperoleh hasil penulagan dan titik angkat pelat sebagai berikut.

Tabel 4. Penulangan Pelat

\begin{tabular}{ccccccc}
\hline \multirow{2}{*}{$\begin{array}{c}\text { Tipe } \\
\text { Pelat }\end{array}$} & \multicolumn{2}{c}{\begin{tabular}{c} 
Ukuran \\
\cline { 2 - 6 }
\end{tabular}} & Ly(m) & Lx(m) & \multicolumn{4}{c}{ Utama } & Pembagi & $\begin{array}{c}\text { Overtopi } \\
\text { ng }\end{array}$ & Angkat \\
\hline A & 2,275 & 1,1 & $\begin{array}{c}\text { D10 } \\
-200\end{array}$ & $\begin{array}{c}\text { D10- } \\
350\end{array}$ & $\begin{array}{c}\text { D10- } \\
350\end{array}$ & D10 \\
\hline B & 2,15 & 1,1 & $\begin{array}{c}\text { D10 } \\
-200\end{array}$ & $\begin{array}{c}\text { D10- } \\
350\end{array}$ & $\begin{array}{c}\text { D10- } \\
350\end{array}$ & D10 \\
\hline C & 2,275 & 1,5 & $\begin{array}{c}\text { D10 } \\
-200\end{array}$ & $\begin{array}{c}\text { D10- } \\
350\end{array}$ & $\begin{array}{c}\text { D10- } \\
350\end{array}$ & D10 \\
\hline D & 2,15 & 1,5 & $\begin{array}{c}\text { D10 } \\
-200\end{array}$ & $\begin{array}{c}\text { D10- } \\
350\end{array}$ & $\begin{array}{c}\text { D10- } \\
350\end{array}$ & D10 \\
\hline E & 2,275 & 1,2 & $\begin{array}{c}\text { D10 } \\
-200\end{array}$ & $\begin{array}{c}\text { D10- } \\
350\end{array}$ & $\begin{array}{c}\text { D10- } \\
350\end{array}$ & D10 \\
\hline F & 2,375 & 1,1 & $\begin{array}{c}\text { D10 } \\
-200\end{array}$ & $\begin{array}{c}\text { D10- } \\
350\end{array}$ & $\begin{array}{c}\text { D10- } \\
350\end{array}$ & D10 \\
\hline G & 2,15 & 1,1 & $\begin{array}{c}\text { D10 } \\
-200\end{array}$ & $\begin{array}{c}\text { D10- } \\
350\end{array}$ & $\begin{array}{c}\text { D10- } \\
350\end{array}$ & D10 \\
\hline
\end{tabular}

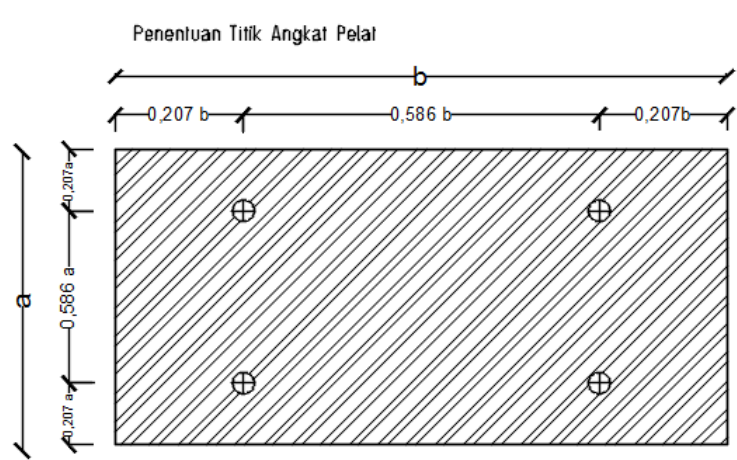

Gambar 4. Letak Titik Angkat

- Penulangan Balok Induk

Dari hasil analisa diperoleh balok berdimensi $400 / 600 \mathrm{~mm}, 350 / 550 \mathrm{~mm}$, $300 / 450 \mathrm{~mm}$, dengan penulangan pada tumpuan, lapangan, dan geser disesuaikan dengan SNI 2847 - 2013 pasal 21, sehingga diapatkan penulangan pada Gambar 5 dan Tabel 5.

Pegangkatan balok induk, disesuaikan dengan PCI Design Handbook,

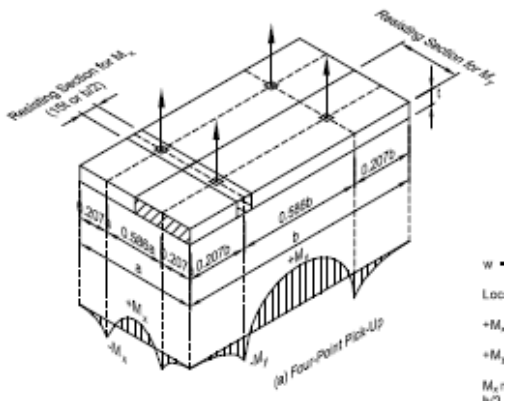

Gambar 5. Titik Pengangkatan Balok

Dimana, nilai:

$$
\mathrm{X}=\frac{1+\frac{4 Y c}{\operatorname{Lxtg} \propto}}{2\left(1 \sqrt{1+\frac{Y t}{Y b}\left(1+\frac{4 Y c}{\operatorname{Lxtg} \alpha}\right.}\right)}
$$

$\alpha=$ Sudut pengangkatan

$\mathrm{L}=$ Panjang bentang

$\mathrm{Yt}=1 / 2 \mathrm{H}=\mathrm{Yb}$

Sehingga didapatkan titik pengangkatan pada Tabel 6 dan digambarkan pada Gambar 6.

Tabel 5. Rekapitulasi Penulangan Balok Induk

\begin{tabular}{cccccccc} 
Kode & Dimensi & \multicolumn{2}{c}{ Tumpuan } & \multicolumn{2}{c}{ Lapangan } & \multicolumn{2}{c}{ Sengkang } \\
\cline { 2 - 8 } & $\mathrm{cm}$ & Atas & Bawah & Atas & Bawah & Tumpuan & Lapangan \\
\hline BI1 & $40 \times 60$ & $4 \mathrm{D} 19$ & $2 \mathrm{D} 19$ & $2 \mathrm{D} 19$ & $3 \mathrm{D} 19$ & $\mathrm{D} 13-140$ & $\mathrm{D} 13-270$ \\
BI2 & $40 \times 60$ & $4 \mathrm{D} 19$ & $2 \mathrm{D} 19$ & $2 \mathrm{D} 19$ & $3 \mathrm{D} 19$ & $\mathrm{D} 13-140$ & $\mathrm{D} 13-270$ \\
BI3 & $35 \times 55$ & $4 \mathrm{D} 19$ & $2 \mathrm{D} 19$ & $2 \mathrm{D} 19$ & $5 \mathrm{D} 19$ & $\mathrm{D} 13-120$ & $\mathrm{D} 13-240$ \\
BI4 & $30 \times 45$ & $4 \mathrm{D} 19$ & $2 \mathrm{D} 19$ & $2 \mathrm{D} 19$ & $3 \mathrm{D} 19$ & $\mathrm{D} 13-100$ & $\mathrm{D} 13-200$ \\
BI5 & $30 \times 45$ & $4 \mathrm{D} 19$ & $2 \mathrm{D} 19$ & $2 \mathrm{D} 19$ & $3 \mathrm{D} 19$ & $\mathrm{D} 13-100$ & $\mathrm{D} 13-200$ \\
BI6 & $30 \times 45$ & $4 \mathrm{D} 19$ & $2 \mathrm{D} 19$ & $2 \mathrm{D} 19$ & $3 \mathrm{D} 19$ & $\mathrm{D} 13-100$ & $\mathrm{D} 13-200$
\end{tabular}

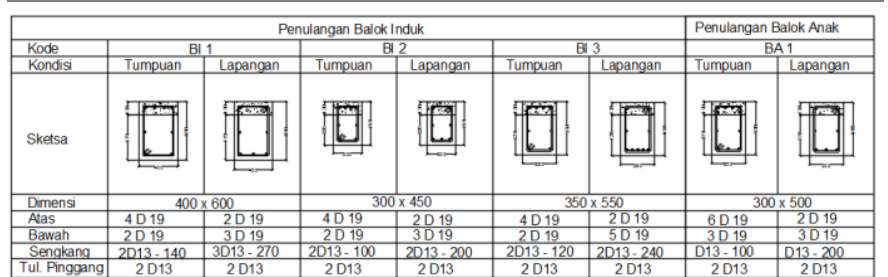

Gambar 5. Penulangan Balok Induk 
Tabel 6. Rekapitulasi

Pengangkatan Balok

\begin{tabular}{|c|c|c|c|c|c|c|c|}
\hline $\begin{array}{c}\text { Be } \\
\text { nta } \\
\text { ng }\end{array}$ & $\begin{array}{l}\text { Di } \\
\text { me } \\
\text { nsi }\end{array}$ & $\begin{array}{c}\text { Tul } \\
\text { ang } \\
\text { an }\end{array}$ & \multicolumn{2}{|c|}{ Sengkang } & \multicolumn{2}{|c|}{$\begin{array}{c}\text { Titik } \\
\text { Angkat } \\
(\mathbf{c m})\end{array}$} & $\begin{array}{c}\text { Dia } \\
\text { met } \\
\text { er }\end{array}$ \\
\hline $\begin{array}{l}\mathbf{m} \\
\mathbf{m}\end{array}$ & $\mathrm{cm}$ & $\begin{array}{l}\text { Uta } \\
\text { ma }\end{array}$ & $\begin{array}{l}\text { Tu } \\
\text { mp } \\
\text { uan }\end{array}$ & $\begin{array}{c}\text { Lap } \\
\text { ang } \\
\text { an }\end{array}$ & $\begin{array}{c}(\mathrm{X} x \\
\mathrm{L})\end{array}$ & $\begin{array}{c}\text { L- } \\
2(X \\
X \text { L) }\end{array}$ & $\begin{array}{c}\text { T.A } \\
\text { ngk } \\
\text { at }\end{array}$ \\
\hline $\begin{array}{c}500 \\
0\end{array}$ & $\begin{array}{c}65 x \\
65\end{array}$ & $\begin{array}{c}12 \mathrm{D} \\
22\end{array}$ & $\begin{array}{c}\text { D13 } \\
- \\
100\end{array}$ & $\begin{array}{c}\text { D13 } \\
- \\
150\end{array}$ & $\begin{array}{c}11 \\
0\end{array}$ & 280 & 16 \\
\hline & $\begin{array}{c}50 x \\
50\end{array}$ & $\begin{array}{c}8 \mathrm{D} 2 \\
2\end{array}$ & $\begin{array}{c}\text { D13 } \\
- \\
100\end{array}$ & $\begin{array}{c}\text { D13 } \\
- \\
150\end{array}$ & $\begin{array}{c}11 \\
0\end{array}$ & 280 & 16 \\
\hline $\begin{array}{c}\mathbf{4 5 0} \\
0\end{array}$ & $\begin{array}{c}65 x \\
65\end{array}$ & $\begin{array}{c}12 \mathrm{D} \\
22\end{array}$ & $\begin{array}{c}\text { D13 } \\
- \\
100\end{array}$ & $\begin{array}{c}\text { D13 } \\
- \\
150\end{array}$ & 90 & 270 & 16 \\
\hline & $\begin{array}{c}50 \mathrm{x} \\
50\end{array}$ & $\begin{array}{c}8 \mathrm{D} 2 \\
2\end{array}$ & $\begin{array}{c}\text { D13 } \\
- \\
100\end{array}$ & $\begin{array}{c}\text { D13 } \\
- \\
150\end{array}$ & 90 & 270 & 16 \\
\hline $\begin{array}{c}310 \\
0\end{array}$ & $\begin{array}{c}65 x \\
65\end{array}$ & $\begin{array}{c}12 \mathrm{D} \\
22\end{array}$ & $\begin{array}{c}\text { D13 } \\
- \\
100\end{array}$ & $\begin{array}{c}\text { D13 } \\
- \\
150\end{array}$ & 70 & 170 & 16 \\
\hline & $\begin{array}{c}50 x \\
50\end{array}$ & $\begin{array}{c}\text { 8D2 } \\
2\end{array}$ & $\begin{array}{c}\text { D13 } \\
- \\
100\end{array}$ & $\begin{array}{c}\text { D13 } \\
- \\
150\end{array}$ & 70 & 170 & 16 \\
\hline
\end{tabular}

Posisi Titik Angkat

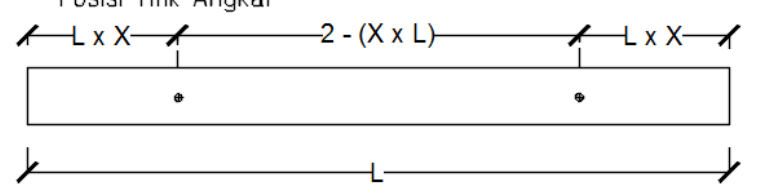

Gambar 6. Letak Titik Pengangkatan Balok

- Penulangan Kolom

Penulangan lentur kolom menggunakan bantuan dari SPColumn sehingga didapatkan hasil rasio tulangan $=1,21 \%$, dengan penulangan $12 \mathrm{D} 22$, $\left(\right.$ As $\left.=4561,59 \mathrm{~mm}^{2}\right)$

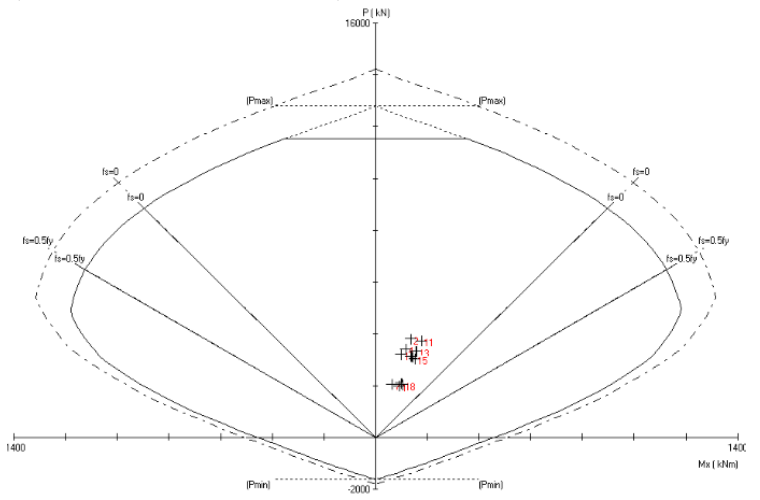

Gambar 7. Diagram Interalsi

Kolom 650 × $650 \mathrm{~mm}$

Penulangan geser dan longitudinal kolom disesuaikan dengan SNI 21, untuk memenuhi Strong Column Weak Beam. Pengangkatan pada kolom sama dengan pengangkatan pada balok. Sehingga didapatkan penulangan dan titik angkat pada Tabel 7 dan Gambar 8.

Tabel 7. Rekapitulasi Penulangan Kolom

\begin{tabular}{|c|c|c|c|c|c|}
\hline \multirow[t]{2}{*}{ Kode } & \multicolumn{2}{|c|}{ Dimensi (cm) } & \multirow{2}{*}{$\begin{array}{c}\mathbf{L b} \\
\mathrm{mm}\end{array}$} & \multicolumn{2}{|c|}{$\begin{array}{c}\text { Titik Angkat } \\
\text { (cm) }\end{array}$} \\
\hline & Komposit & Pracetak & & $\begin{array}{c}\mathrm{X} x \\
\mathrm{~L}\end{array}$ & $\begin{array}{c}\mathrm{L}-2(\mathrm{X} \\
\mathrm{x} \mathrm{L})\end{array}$ \\
\hline BI1 & $40 \times 60$ & $40 \times 47$ & 7500 & 160 & 390 \\
\hline BI2 & $40 \times 60$ & $40 \times 47$ & 8250 & 180 & 465 \\
\hline BI3 & $35 \times 55$ & $35 \times 42$ & 5600 & 120 & 320 \\
\hline BI4 & $30 \times 45$ & $30 \times 32$ & 2600 & 60 & 140 \\
\hline BI5 & $30 \times 45$ & $35 \times 32$ & 7250 & 160 & 405 \\
\hline BI6 & $30 \times 45$ & $30 \times 32$ & 3750 & 80 & 215 \\
\hline
\end{tabular}

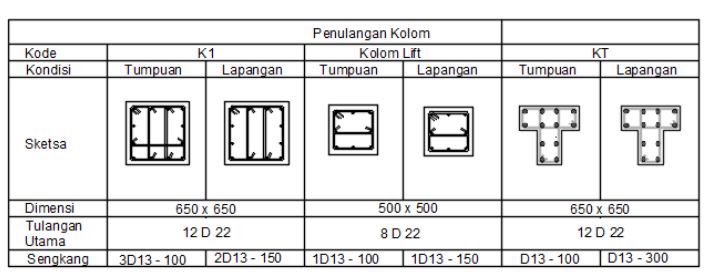

Gambar 8. Penulangan Kolom

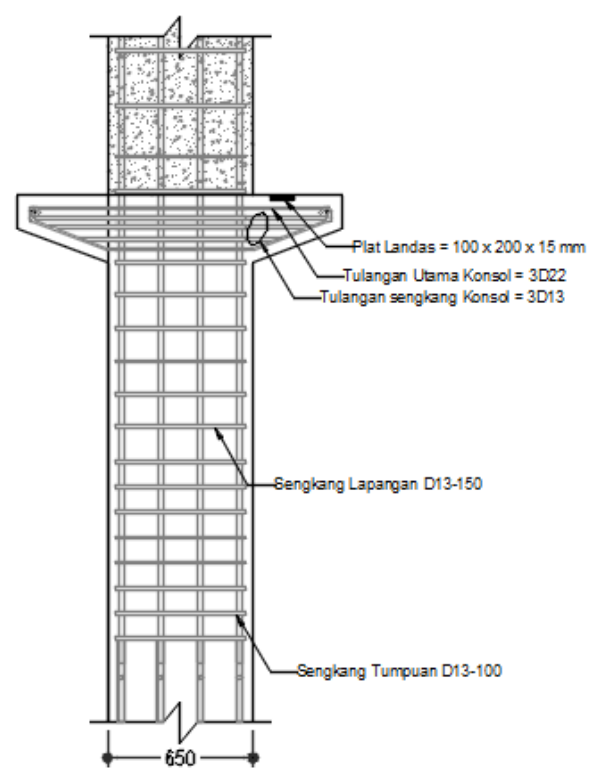

\section{DETAIL PENULANGAN KOLOM PRACETAK}

Gambar 9. Penulangan Kolom Pracetak

\section{Perencanaan Sambungan}

- Sambungan Pelat - Balok 
Disesuaikan dengan SNI 2847 2013 pasal 12.5.1. Sehingga didapatkan, $\mathrm{L}_{\mathrm{dh}}=160 \mathrm{~mm}$.

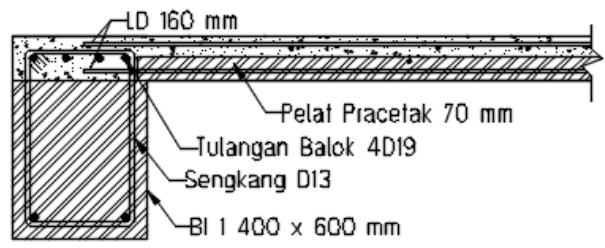

Sambungan Pelat-Balok

Gambar 10. Detail Sambungan Pelat Balok

Pelat diberi overtopping yang dicor bersamaan dengan balok.

- Sambungan Balok Induk - Balok Anak

Sambungan antara BI - BA menggunakan stek dari BI yang kemudian overlapping dengan penyaluran dari BA sesuai dengan SNI 2847 - 2013 pasal 12.3.2 dan 12.5.2. Didapatkan $\mathrm{L}_{\mathrm{dc}}$ dan $\mathrm{L}_{\mathrm{dh}}$ sebesar:

$\mathrm{L}_{\mathrm{dc}} \quad=350 \mathrm{~mm}$.

$\mathrm{L}_{\mathrm{dh}} \quad=350 \mathrm{~mm}$.

Ld overlap $=300 \mathrm{~mm}$.

Pada bagian tulangan overlap akan dilakukan pengecoran di tempat.

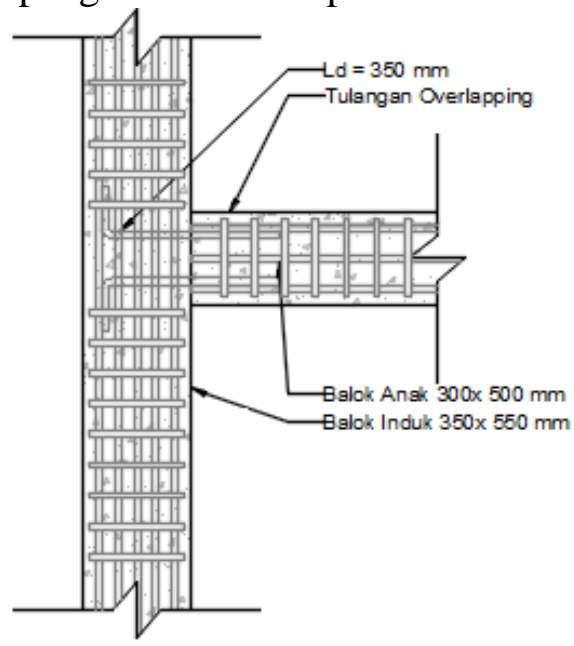

DETAIL SAMBUNGAN BALOK INDUK \& ANAK

Gambar 11. Sambungan BA - BI

- Sambungan Balok Induk - Kolom Samungan balok - kolom dengan konsol sesuai dengan SNI 2847 - 2013 pasal 11. Pada balok diberi panjang penyaluran sesuai dengan SNI 2847 2013 pasak 12.3 dan 12.5, yang kemudian akan dicor ditempat bersamaan dengan kepala kolom, overtopping pelat dan balok.

Pada konsol dan balok diberi penahan retakan akibat geser dari kedua ujung seperti pada Gambar 12.

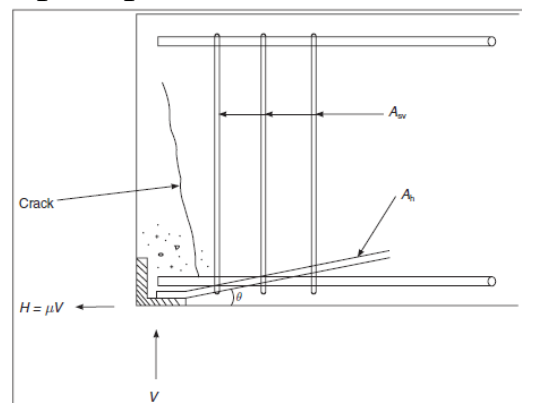

Gambar 12. Tulangan Penahan Retak Dengan menentukan besaran $\mathrm{H}$, dengan:

$$
\begin{aligned}
& \mathrm{H}=\mu \times \mathrm{V} \\
& \text { Dimana: } \\
& \mathrm{H}=\text { Gaya yang terjadi } \\
& \mu=\text { Koefisien friksi } \\
& \mathrm{V}=\text { Gaya geser }
\end{aligned}
$$

Kemudian menentukan Panjang Ah dengan Ld pada pasal 12.2.1 SNI 2847 - 2013. Sehingga didapatkan penulangan seperti pada Gambar 13.

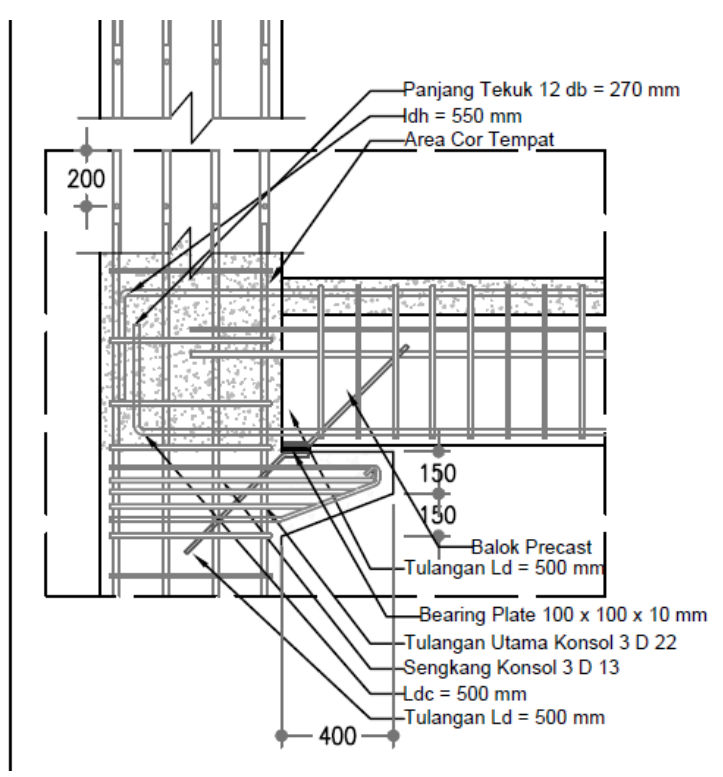

Gambar 13. Sambungan Balok Kolom 
- Sambungan Kolom - Kolom

Sambungan antar kolom menggunakan produk $N M B$ Splice Sleeve dengan pemilihan disesuaikan dengan spesifikasi dari brosur.

Penyambungan ini dilakukan dengan memasukkan bahan grouting.

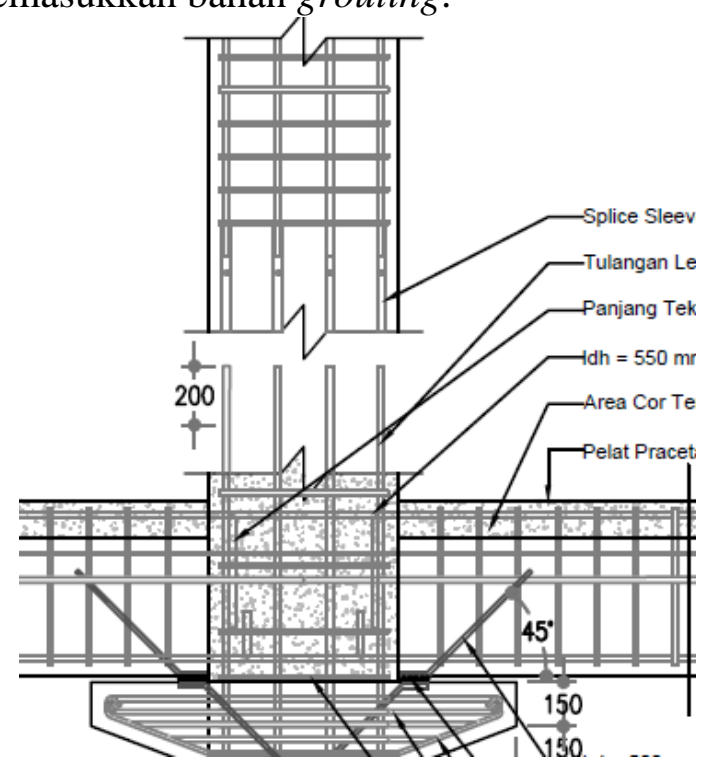

Gambar 14. Sambungan Kolom Kolom

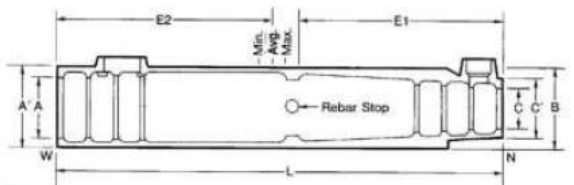

Gambar 15. Detail NMB Splice Sleeve

\section{KESIMPULAN}

Berdasarkan hasil perencanaan dan analisis yang dilakukan, maka dapat disimpulkan bahwa berdasarkan perencanaan dimensi, pada balok didapatkan sebesar $300 / 450 \mathrm{~mm}$, 400/600 mm, dan 350/550 $\mathrm{mm}$ dengan penulangan utama D19 dan tulangan geser D13. Pada pelat yang mengacu pada SNI 2847 - 2013 pasal 9.5.2, didapatkan tebal $130 \mathrm{~mm}$ dengan tebal overtopping $60 \mathrm{~mm}$ dan pelat pracetak half slab $70 \mathrm{~mm}$. Sedangkan pada kolom, didapatkan dimensi

$650 / 650 \mathrm{~mm}$, dengan penulangan utama $12 \mathrm{D} 22$.
Pada penulangan angkat setiap elemen,

pada pelat digunakan empat titik angkat yang disesuaikan dengan PCI design handbook, dengan kedalaman angkur 50 $\mathrm{mm}$ dan tulangan angkat D10. Pada Balok digunakan dua titik angkat, dengan kedalaman angkur $150 \mathrm{~mm}$ dan tulangan angkat yang digunakan D13. Diletakkan pada jarak yang sudah ditentukan dari masing- masing ujung balok. Sedangkan pada kolom, digunakan tiga titik angkat yaitu dua buah pada sisi yang sama seperti balok dan satu sisi pada atas kolom. Digunakan angkur D16 dengan kedalaman $160 \mathrm{~mm}$.

Pada sambungan antar elemen dapat disimpulkan, sambungan pelat dan balok menggunakan $\mathrm{Ld}=160 \mathrm{~mm}$ yang nantinya akan dicor bersamaan dengan topping balok dan kepala kolom. Untuk sambungan Balok anak - balok induk menggunakan stek tulangan yang diberi panjang penyaluran sebesar $300 \mathrm{~mm}$. Sedangkan pada sambungan Balok dan kolom menggunakan konsol pendek dan panjang penyaluran. Pada sambungan kolom - kolom menggunakan produk dari NMB Splice Sleeve yang disesuaikan dengan spesifikasi.

Dalam penelitian ini, telah dilaksanakan sesuai dengan prosedur, namun masih memiliki keterbatasan yaitu dalam penelitian ini tidak mengkaji besaran kekuatan sambungan dari hasil perhitungan dalam SNI 2847 - 2013, hanya memenuhi persyaratan dari peraturan yang digunakan. Untuk penelitian lanjutan, disarankan untuk mengkaji lebih lanjut mengenai kekuatan sambungan yang digunakan.

\section{DAFTAR PUSTAKA}

[1] Badan Standardisasi Nasional. 2013. Persyaratan Beton Struktural Untuk Bangunan Gedung, SNI 2847:2013 
[2] Badan Standardisasi Nasional. 2012. Tata Cara Perancangan Beton Pracetak dan Beton Prategang Untuk Bangunan Gedung, SNI 7833:2012.

[3] Elliot, Kim S. 2001. Precast Concrete Structures. Butterworth Heinemann.

[4] Klana, Kusuma I., Mudji Irmawan, and Endah Wahyuni. 2017. Modifikasi Perencanaan Struktur Gedung Ibis Styles Hotel dengan Metode Beton Pracetak. Vol. 6 No.2. Jurnal Teknik ITS.

[5] Precast/Prestressed Concrete Institute. 2004. PCI Design Handbook 6th Edition.

[6] Trie Sony Kusumowibowo, Endah Wahyuni. 2017. Modifikasi Perenvanaan Gedung Rumah Sakit Umum Daerah (RSUD) Koja Jakarta Dengan Metode Pracetak. Vols. 6, No.1. Jurnal Teknik ITS.

[7] IAPPI. 2015. Modul Pelatihan dan Sertifikasi Pengawas Konstruksi Beton Pracetak Bangunan Gedung.

[8] Fadilla, Elvi dkk. 2009. Studi Eksperimental Sambungan KolomKolom Pada Sistem Beton Pracetak Dengan Menggunakan Sleeves. Makalah HAKI.

[9] Tumilar, Steffie. 2011. Prosedur Analisis Struktur Beton Akibat Gempa Menurut SNI 1726-2010. Seminar HAKI.

[10] Ervianto, Wulfram. Studi Implementasi Teknologi Beton Pracetak Bagi Banguan Gedung. Yogyakarta.

[11] Wiranata, Arga. Studi Analisis Sambungan Balok-Kolom Dengan Sistem Pracetak Pada Gedung Dekanat Fakultas Teknik Universitas Brawijaya Malang. Malang.

[12] Hendrawan Wahyudi, Hery Dwi Hanggoro. 2010. Perencanaan Struktur Gedung BPS Provinsi Jawa Tengah Menggunakan Beton Pracetak. Semarang.
[13] Khakim, Zainul et. all. 2011. Studi Pengerjaan Beton Antara Pracetak dan Konvensional Pada Pelaksanaan Konstruksi Gedung Dengan Metode AHP. Malang

[14] Widodo Soetjipto, Jojok. Analisa Perbandingan Pelaksanaan Pembangunan Menggunakan Beton Konvensiobal Dengan Elemen Beton Pracetak Pada Bangunan Tingkat Tinggi. Jember.

[15] Irawan, Djoko. et. all. 2014. Kajian Sambungan Antar Pelat Pracetak Pada Sistem Half Slab Yang Menerima Beban Lentur. Surabaya.

[16] Susanto Felix, Vincentius. et. all. 2018. Desain Modifikasi Apartemen One East dengan Menggunakan Precast Dual System Sesuai dengan Peraturan ACI 318M-14. Vol 7 No. 1. Jurnal Teknik ITS. Surabaya.

[17] Riyanto, Hery. Perilaku Statis Struktur Beton Pracetak dengan Sistem Sambungan Basah. Lampung.

[18] Irawan, Djoko. 2017. Model Sambungan Antar Komponen Beton Pracetak. Surabaya.

[19] Rahmadhan Yusuf, Gita. et. all. 2014. Studi Perencanaan Desain Sambungan Balok - Kolom dengan Sistem Pracetak Pada Gedung Dekanat Fakultas Teknik Universitas Brawijaya Malang. Malang.

[20] Adi Yuniarto, Rudi. et. all. 2014. Perilaku Kekuatan Sambungan Kolom Pada Sistem Beton Pracetak. Semarang. 